\title{
REAL TIME ENTERPRISE AS A PLATFORM OF SUPPORT MANAGEMENT SYSTEMS
}

\author{
Jerzy KISIELNICKI*, Marek Michal MARKOWSKI** \\ University of Warsaw, Faculty of Management, POLAND \\ *e-mail: jkisielnicki@wz.uw.edu.pl \\ **e-mail: marekmmarkowski@gmail.com
}

\begin{abstract}
The current, fast market changes require enterprises to dynamically adapt the way they conduct their business. This poses many challenges for information technology. Market requirements for immediate response to business changes became the basis of the idea of a real-time information processing (RTE) company. RTE provides real-time information to employees and business partners. Integrated IT systems supporting management constitute a common platform - the foundation of a real-time enterprise. The aim of the article is to present the basic problems of building an IT system that is the basis of a realtime information processing (RTE) company. It is a summary of our work on this type of system. The article justifies the thesis about the need to build a system for the RTE's requirements and the conditions of its implementation. Such a system is designed to provide employees and business partners with the information they need in real time. The use of integrated systems such as ERP, CRM, SCM, and so on provides the ability to implement the main business processes of a real-time enterprise. The article presents both literature analysis and the characteristics of own work on designing IT systems for RTE. Particular attention was paid to the analysis of success factors (determinants) in system design and the use of MUST methodology (MUST is a Danish acronym for theories of and methods for design activities). The final part of the article presents a proposal for further work on IT systems for RTE in the context of existing trends such as DARQ technology (Distributed Ledger, Artificial Intelligence, Extended Reality, Quantum computing).
\end{abstract}

Keywords: RTE, Real Time Enterprise, computer systems integration, business processes, IT design determinant, IT systems platform.

JEL Classification: L830, L230.

\section{1}

Introduction

The present age is a period of changes and comprehensive development. The digital economy is fundamentally changing modern management. The need to react immediately to business changes, reduce the time needed to implement economic processes, obtain information very quickly and share it, have become the foundation of the idea of an enterprise processing data in real time (Real Time Enterprise, RTE).

IT systems should provide information to employees, customers, suppliers and other business partners in real time. The next requirement is to ensure timeliness and consistency in all IT systems operated in the RTE enterprise. In the article, we justify the thesis about the need to build a system for RTE enterprises and present the conditions for their implementation. The use of appropriate IT systems influences the effective management of the organization. RTE issues are the subject of our many years of research, which were partially presented in articles Markowski (2012) and Kisielnicki and Markowski (2021).

The research procedure used was as follows: The first stage of our research is the analysis of the literature and published research reports. Then, based on our own research and experience in project implementation, the requirements that must be met by these systems in the field of: (1) implementation or development of IT systems; (2) integration of people, information and business processes; (3) change management and business processes continuous improvement; and (4) IT design project. To determine the requirements, such surveys were used remotely filling in (CAWI).

Due to the need for an immediate reaction of the company and the associated appropriate approach of employees, the MUST methodology was applied to the research, which emphasizes the high commitment of human resources and obtaining a consensus on the 
goals and methods of implementation as an important element of efficient preparation for IT implementation. Hence, based on MUST, the research was conducted among 4 categories of people: IT designers or consultants, users, management and other stakeholders.

\section{Background}

The way enterprises conduct their business is constantly adapting to constant market changes and increasing competition. Thanks to technological progress, enterprises develop business flexibility, using new business models and implementing innovations (Sikri, 2015). It requires the use of tools that ensure access to critical information at the right time and place for the right users. Therefore, reducing delays in business operations is the goal and way of implementing a real-time system (Kejariwal and Orsini, 2018).

The issue of using information technology in developing RTE capabilities requires analytical work (Park, et al., 2020).

Real-time economy exists in many different industries, for example, finance, telco, fashion (Kekwaletswe and Lesole, 2016), software production (Martínez-Fernández, 2018). Real-time information processing, that is, RTE, is also the basis of the Smart Factory in the Industry 4.0 concept (Herrmann, 2018).

RTE is an enterprise that processes information in real time. It is an organization focused on quick response to market needs, immediate information exchange between internal groups, transparency and quick decision-making (Šibalija, 2018). RTE is the ability to quickly detect and manage important business events (Park, et al., 2020).

The competitive advantage of real-time enterprises (RTE) is the result of faster than other enterprises reacting to changing business conditions and emerging opportunities (Rudowski, 2015).

The pursuit of RTE is associated with the digital transformation of the enterprise - the use of information technology to transform user experiences, as well as business processes and models to significantly improve the performance or reach of the enterprise (Leonardi, 2020).
The business requirements for RTE require extensive use of information technology in the field of data acquisition, processing, analysis and sharing. It is connected with the necessity to use various, often homogeneous information systems and their integration. proper preparation, operation and maintenance. Therefore, RTE can be talked about as an enterprise based on an interoperable platform of cooperating management support systems.

Real Time Enterprise is the subject of many years of research conducted by us. The article is a summary of the findings so far and a presentation of the results obtained recently. Particular attention was paid to the RTE main functionality, component IT systems, IT technology as a factor integrating processes, information and people, concept of design project for RTE based on MUST methodology, change management and continuous improvements of the enterprise processes, extending the authors' previous studies (f.e. Markowski, 2012; Kisielnicki and Markowski, 2021).

When considering the implementation of the research, an optimal methodology was searched, which:

1) It concerns the preparation of an IT project (IT design) and is not limited to implementation - due to this research topic.

2) It refers to the common vision of the target solution - because preparation for the implementation of real-time IT solutions for business is related to the development of a coherent vision of the target solution and its implementation.

3) It ensures proper cooperation between the parties involved, including the proper flow of knowledge - because the implementation of the IT system design for RTE requires perfect cooperation between future users and IT specialists.

4) It is used by enterprises of various industries with advanced IT environments - because preparing the implementation of IT systems and solutions for RTE and their integration is associated with a high complexity of tasks and interdependencies. Specific methodologies applicable in IT were analyzed, ranging from universal ones, that is, PRINCE 2, through domain/product, for example, ASAP (SAP), RWM (SAS), AIM (Oracle), Sigma (Sage) or own used by large organizations, for example, Chestra (Siemens) or iQMS (GSK). 
The MUST methodology is most relevant to the research topic. MUST is a Danish acronym for theories and design methods. The MUST method was developed on the basis of projects made in Danish and American companies. It assumes that the introduction of new IT systems requires the development of a solid foundation for users, management, IT specialists, managers and IT specialists, minimizing the risk of developing unrealistic, ineffective and burdensome systems. In order to implement the vision of an IT project, such a solution must not only be technically correct, but it is also necessary to agree and accept its vision in the organization. A pragmatic approach, it is assumed that IT specialists need knowledge of the context of use, and users need knowledge of technological options (Bødker, et al., 2009).
The common vision (coherent vision) of the target solution includes the development of: (1) IT systems and broadly understood information technology, (2) the way an organization works, and (3) appropriate competences of users who work in a changed organization with new IT systems.

\section{Real-time Enterprise as a platform of support management systems}

\subsection{RTE business requirements for IT}

In many business areas, competition relates to time quick response is a key element of success, minimizing costs and maintaining excellent quality of operations (Cundius and Alt, 2017).

Table 1. Examples of real-time (or near-real-time) processes in various industries

and IT solutions applied for their servicing (Source: Kisielnicki and Markowski, 2021)

\begin{tabular}{|c|c|c|c|c|}
\hline No. & Industry & $\begin{array}{l}\text { Example of real- } \\
\text { time or near-real- } \\
\text { time business } \\
\text { process RTE }\end{array}$ & $\begin{array}{l}\text { Short description } \\
\text { of procedures / main points }\end{array}$ & $\begin{array}{c}\text { Examples } \\
\text { of applied IT systems }\end{array}$ \\
\hline 1 & Finance & $\begin{array}{l}\text { Credit card } \\
\text { payment }\end{array}$ & $\begin{array}{l}\text { Purchasing a product or service from } \\
\text { an acceptant } \\
\text { Authorization } \\
\text { Transaction provision } \\
\text { Payment to acceptant }\end{array}$ & $\begin{array}{l}\text { Card servicing systems, } \\
\text { fraud detection, BI,... }\end{array}$ \\
\hline 2 & $\begin{array}{l}\text { Telecommuni- } \\
\text { cation }\end{array}$ & $\begin{array}{l}\text { New client } \\
\text { (technical } \\
\text { servicing) }\end{array}$ & $\begin{array}{l}\text { Selection of service, entering the } \\
\text { agreement, SIM card activation, } \\
\text { Propagation of card recognition }\end{array}$ & $\begin{array}{l}\text { Call Center, CRM, Bill- } \\
\text { ing Systems, RMCA } \\
\text { and rating, OSS (net- } \\
\text { work layer), BI }\end{array}$ \\
\hline 3 & Retail & $\begin{array}{l}\text { Selling } \\
\text { the product } \\
\text { in the internet }\end{array}$ & $\begin{array}{l}\text { Selection of product from the internet } \\
\text { shop, choice of delivery and payment } \\
\text { options }\end{array}$ & $\begin{array}{l}\text { Internet Sales app, ERP, } \\
\text { BI }\end{array}$ \\
\hline 4 & $\begin{array}{l}\text { Utilities, energy } \\
\text { sector }\end{array}$ & $\begin{array}{l}\text { Malfunctions } \\
\text { reporting }\end{array}$ & $\begin{array}{l}\text { Information about the network } \\
\text { malfunction, reporting affected } \\
\text { individuals, sending a repairs team }\end{array}$ & $\begin{array}{l}\text { SCADA, call center, } \\
\text { billing/customer service } \\
\text { system, Workforce } \\
\text { Management Systems, } \\
\text { ERP, BI }\end{array}$ \\
\hline 5 & Industry/Sale & Sale of a vehicle & $\begin{array}{l}\text { Initial vehicle configuration, Final } \\
\text { vehicle configuration, pricing, entering } \\
\text { the agreement, date of receipt } \\
\text { confirmation }\end{array}$ & $\begin{array}{l}\text { CRM, sale support sys- } \\
\text { tems, ERP, SCM, BI }\end{array}$ \\
\hline 6 & $\begin{array}{l}\text { Pharma - manu- } \\
\text { facture and sale } \\
\text { of pharmaceuti- } \\
\text { cals }\end{array}$ & $\begin{array}{l}\text { Stock level } \\
\text { reporting }\end{array}$ & $\begin{array}{l}\text { Up-to-date, detailed information on } \\
\text { stock levels and their status }\end{array}$ & ERP, SCM, WMS, BI \\
\hline
\end{tabular}


The key issue for organizations in maintaining a competitive advantage is the organizational ability to quickly detect and manage important business events that turn into opportunities and threats (Park, et al., 2017).

Currently, one of the basic business needs is the use of tools enabling access to critical information at the right time and place. This involves identifying new business opportunities, minimizing delays in main business processes, speed and quality of decisions made, improving customer relationships, avoiding failures and improving flexibility, as well as increasing return on investment and improving employee productivity at every level of the organization.

IT is one of the most important factors that can determine organizational capabilities to cope with environmental turbulence (George, et al., 2016). Thanks to the integration of internal and external data, effective information analysis and communication between business partners, RTE can operate extremely quickly.

Real-time information processing is also the central element of the Smart Factory in the Industry 4.0 concept (Herrmann, 2018) and its important element the cyber-physical system (CPS), where industrial machines exchange information in real time with other machines or connected objects, controlling mutual actions. This revolutionary idea is based on IT, planning and controlling the company's resources in real time, controlling production, carrying out planning, connecting systems, sensors, actuators, robotics and so on (Dachs, et al., 2019), fully integrating suppliers and customers and covering the entire value chain.

In an ideal RTE model (Snabe, et al., 2009):

1) Information flows smoothly inside and outside the enterprise, without barriers;

2) Business processes are constantly monitored and are constantly improved;

3) Aggregated information about business processes is the basis for quick response to changes in the enterprise and outside it;

4) There is a flexible automation of key business processes.
The speed at which new opportunities emerge or new products and services are introduced is steadily increasing over time in many industries not only in high-tech industries, but also in non-high-tech industries (Park, et al., 2020). Examples of industries and their real-time processes are presented in Table 1.

Summarizing the above information, it can be stated that at the basic level, IT solutions for RTE should enable:

1) Real-time monitoring of the company and its environment;

2) Real-time access to information;

3) Acceleration of business processes.

\subsubsection{Real-time monitoring}

In business today, many values that were once viewed as static are now becoming increasingly volatile. Despite this, however, many day-to-day business transactions are not effectively monitored and supervised (Yousef, et al., 2018).

Efficient management is possible only when we have good quality information about the organization and its environment (Kisielnicki, 2017).

Monitoring the operation of an organization in real time is one element in the pursuit of a real-time enterprise. Organizations respond to economic events at different speeds and with varying levels of complexity. The simplest solution is to get reports informing about what happened. More complex queries allow you to pinpoint the cause of an event. Forecasting requires analytical models and constant data refreshing to be informed about the current state of the organization. At the most advanced level, the organization monitors itself and its surroundings on an ongoing basis and, depending on the events, takes predefined actions. There is therefore no significant delay between the incident and the organization's response. The premise of RTE is to react at a rate of fractions of a second, which exceeds the human ability to obtain and process information, analyze and answer it.

Real-time monitoring of the organization and its environment is related to, among others organization's ability to detect critical events, report, make decisions and provide excellent business insight. It allows you 
to track the status of processes and applications, monitor the most important business measures (i.e., KPI), detect and act on business opportunities. Sources of such information may be business IT systems, that is, ERP, BI, CRM, SCM, MES, SCADA, measurement tools, RFID gates, IoT objects, etc.

Continuous measurement of the organization's activities and immediate access to key business indicators (Tank, 2015) is possible thanks to IT solutions. In this case, the acquisition of measurement data and their transformation into useful information in real time becomes a simpler and more automated process.

Fig. 1 shows exemplary enterprise systems used in real-time monitoring, the central element of which is the management cockpit, fed with data from BI \& Real Time BI.

$\mathrm{BI}$ and Real-time BI receives data from:

- ERP and business partners' systems integrated with ERP,

- CRM, which with the help of Artificial Intelligence supports many channels of contact with the client,

- SCM, MES and SCADA connected, among others with elements of industrial automation, IoT or RFID readers.

In order not to complicate the image, possible integrations between ERP, CRM, SCM and other such systems were omitted.

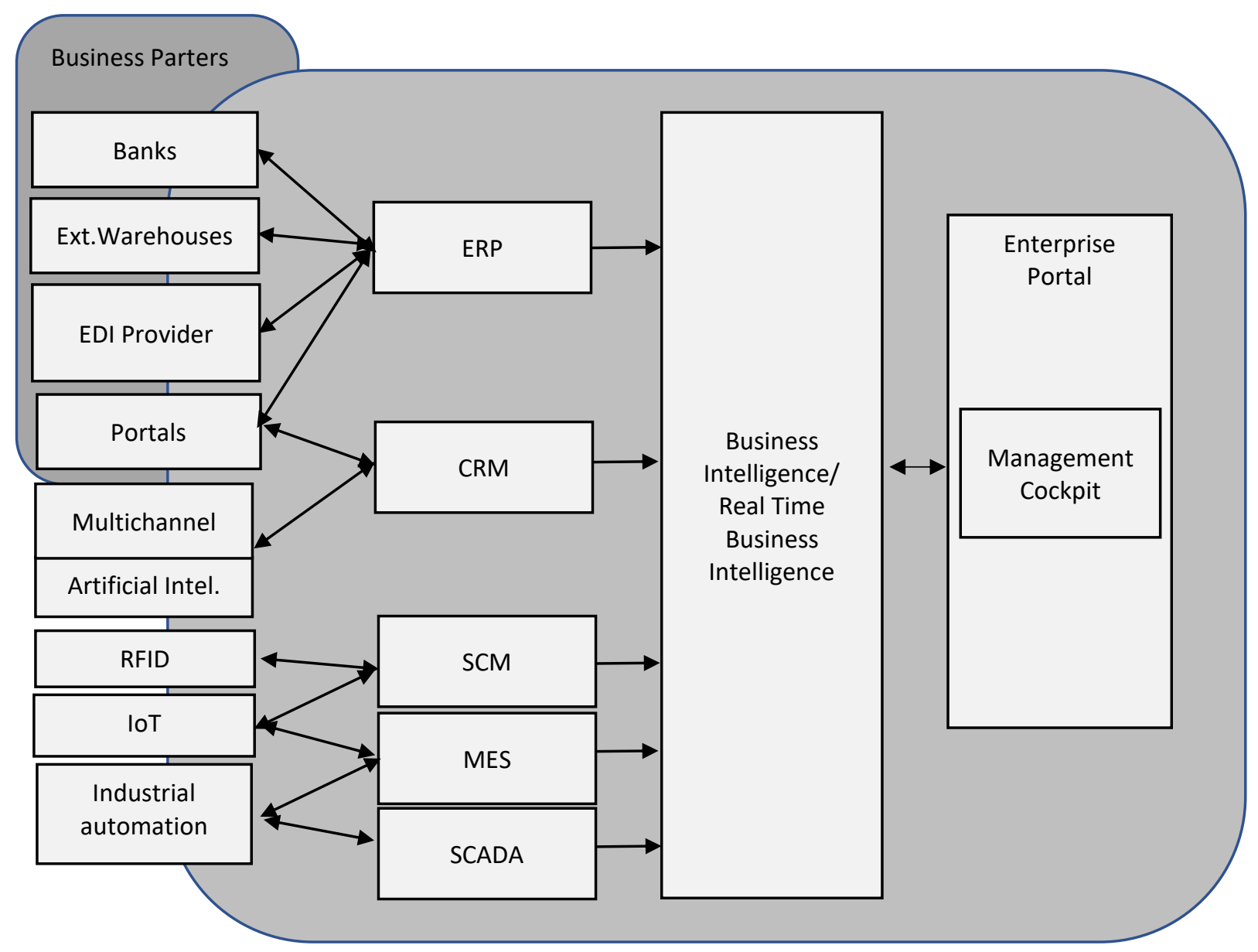

Figure 1. Proposal to use the management cockpit as a central element of RTE monitoring (Source: own research)

The issue of precise monitoring is related to the generation of very large amounts of data (Song, et al., 2017). They create the so-called a stream of events that can be processed in real time (Zhang, et al., 2018) that can be analyzed with complex event processing (CEP) solutions detecting in real time situations relevant or critical for the monitored area (Garro, et al., 2016; Macià, et al. 2016). 
Processing real-time information from sensors enables continuous monitoring of almost every link in the supply chain, from product design to raw material purchasing, production, transportation, storage, distribution and after-sales service. It also allows for the provision of real-time services (Lai, et al., 2018) or the provision of information on the condition of machines and devices ( $\mathrm{Nel}$ and Jooste, 2018) for remote access customers.

Data sources can also be RFID tags or IoT objects. Sometimes this requires a detailed definition of events (Patri, et al., 2016).

\subsubsection{Real-time access to information}

Decision-making requires fast and reliable real-time information. It applies to many areas of business, including customer service, sales, logistics and production.

The value of the data is related to their availability to analyses and forecasts, support in making decisions requires access to various data. Market information quickly becomes obsolete, and windows of strategic opportunities and threats close quickly (Park, et al., 2020).

Real-time data availability can improve day-to-day management activities, support strategic planning, achieve business goals, and affect the speed and accuracy of decision making.

The timeliness of data in IT systems should define the business needs of the enterprise. In the case of a company implementing RTE strategies, information is provided when needed, in an easy way, in an appropriate graphic form and in accordance with the defined business rules (Mathes, 2016).

Real-time access to information on business performance is also critical for corporations that respond to an ever-changing business environment with increasing levels of competition.

Information may come from the company's IT systems, that is, ERP, CRM, SCM, MES (Hwang, et al. 2018), BI operating in a traditional and real-time manner. Real-time analytics are becoming more and more needed, although their application in business is still limited (Korotina,, et al., 2015). With real time BI, the data is analyzed as soon as it reaches the organization. Up-to-date data at the operational and tactical level (Tank, 2015) enable immediate response (Davcheva and Benlian, 2018).

Real-time enterprise transaction processing and analysis (RTE) can be handled with in-memory database solutions (Hwang, 2018).

\subsubsection{Acceleration of business processes}

Each task has a time buffer - the amount of time given for organizations to finish the task without delaying other tasks that are dependent on it (Park, et al., 2020).

For companies implementing the RTE concept, it is necessary to be able to implement business processes in real time (Ouarhim and Baïna, 2019), based on information available from all sources, automatically and delivered immediately to the decision-making place.

The term "real-time process" is used when there is little or no delay between the process input and output. This applies to computerized and automated workflows (Kaymaz, 2015).

There are four basic types of delays in the implementation of complex business processes that can be handled with the use of information technology (Vasarhelyi, et. al., 2010):

- delays within processes - the time needed for execution of the process; they are minimized by automation of subsequent stops in the process,

- delays between systems: the time of transferring data between processes,

- delays in decision making: the time needed to make decisions,

- delays in implementation of already made decisions.

The goal of RTE is to reduce the time of business processes to run in real time. A typical RTE enterprise must therefore review and change current business practices in order to eliminate business process delays by checking their temporal characteristics such as activity execution time, minimum and maximum time, start time.

The effects of IT functioning are best visible at the level of business processes. Properly implemented IT can shorten the time of business processes and decision-making and provide a competitive advantage. Automation of business processes reduces the time 
of their implementation from hours or minutes to the game by humans to seconds or fractions of a second.

As our research has shown, real-time enterprise (RTE) strategies automate economic processes across systems, media and across enterprise boundaries, reduce delays, eliminate non-value-added activities, and change the nature of economic processes and the understanding of their automation.

At the strategic level, the automation of business processes is supported by the concept of business process management (BPM), the development of which is assumed to be CEP (Complex Event Processing). CEP's task is to respond in a specific way to exceptions or other predefined indicators.

A large number of IT systems is usually required to support business processes covering various functional areas of an enterprise. IT integration enables the coordination of such activities, for example, in the field of product design, procurement, production and supply chain management.

\subsection{Determinants of the IT system for RTE}

In many business sectors, there are real-time or nearreal-time business processes supported by a number of IT systems integrated in various ways.

It seems impossible to function RTE without the support of IT technology. Nevertheless, organizational changes must be carried out in the company, which will be "consolidated" by IT.

The goal is, among others, addressing activities that generate more value (Hongren, et al., 2015) and enable optimization of business processes, for example, based on defining Lean goals, preparing a time course analysis or modifying the qualifications of specialists.

In order to achieve the goals set for RTE, among others, implementation, modernization and integration of various IT systems. It can be checked that the IT system being the source of RTE will be the system of systems (Hofman and Bastiaansen, 2014).

The use of a rapidly developing domain - Artificial Intelligence (Pan, 2016; Makridakis, 2017) - may be of key importance for the implementation of the RTE concept. At a higher organizational level, artificial intelligence can be seen in terms of support for the automation of business processes, gaining insight through data analysis, and actively engaging customers and employees (Davenport and Ronanki, 2018).

In the literature on the subject, the following RTE business areas can be identified for which AI can be applied: (e.g., Brynjolfsson and McAffee, 2017; Davenport and Ronanki, 2018; Dirican, 2015; Kolbjørnsrud, et al. 2016; Wua, et al., 2017; Zhang and Chen, 2017):

- customer service,

- monitoring, reporting, business and R\&D analyzes, forecasts,

- support in making decisions,

- intelligent production,

- administrative support.

Preparation of a comprehensive IT system for information processing in RTE is a complicated matter. Based on the analysis of the literature on the subject and own research, it is possible to present a certain set of conditions supporting the creation of an IT system for RTE, which is a type of management support systems platform. This applies to the following areas, which will be discussed further:

1) Implementation of new or development of existing IT systems in the core areas of the business, that is, finance, production, sale and distribution, and supplies;

2) Integration of the IT systems in the scope of business processes, information and human resources;

3) Secure IT tools for the change management and continues improvement of the enterprise's processes;

4) Use of proven methodologies for IT design project for RTE.

Enterprises to operate in specific business areas use a number of IT systems, including ERP for core back office activities, CRM for customer relationship management, SCM for transport, mobile and smart devices. All this information technology is used to change and enhance business processes, customer relationships and the ways to innovate produces and services, thus transforming competitive landscapes in all economic sectors (George, et al., 2016). 
For RTE, these systems:

1) They support the implementation of all or part of business processes;

2) To function as a data source for other IT systems in the enterprise.

Hence, for the implementation of RTE, it seems important to analyze the possibility of supporting the required real-time functionalities by the existing enterprise systems or, possibly, the implementation of new IT systems. Examples of determinants regarding implementation of new or development of existing IT systems are listed in Table 2

Those business processes that are implemented in various IT systems often require information exchange and interpersonal interaction. Continuity of process implementation is associated with the need to integrate information and human resources. Information technologies that enable sharing information and combining resources beyond the boundaries of the enterprise come to the rescue (Song, et al., 2017). For the implementation of RTE, it is important that the integration of IT systems is necessary to reduce delays in the implementation of business processes, access to information and efficient human work.

IT integration is concerned with the seamless interconnection of people, processes and information that can transcend in an environment spanning multiple heterogeneous platforms and protocols as well as multiple access devices (McDonald, 2015).

Thanks to integration, companies' IT systems can constitute a common IT platform - the foundation for the implementation of RTE activities.

From the business side, striving to integrate the enterprise requires organizing organizational procedures, treating IT as the foundation for their implementation (Cundius and Alt, 2017).

Examples of IT systems/solutions and areas of their business support for the integration of people, information and processes in the context of determinants of IT system for RTE are shown in Table 2.

In order to create an appropriate IT environment implementing the RTE concept, proper management of organizational changes and modification of existing IT solutions is required. Since organizations are social systems, the way they deal with change is essential to the success and survival of a company. Change in the organization is associated with risk and therefore must be effectively managed.

This also includes the use of appropriate human resource management (Yuan, 2016).

Change management can be discussed in the context of the process of continuous review of the direction, structure and capabilities of the organization in order to meet the constantly changing needs of internal and external customers. Proper organizational change covers such areas as (Karnouskos, 2015): employee, leadership, training and development, awards and recognition, culture, policy and IT systems.

In order to ensure the flexibility of business processes and to react quickly to new requirements, it is necessary to implement changes in the IT environment as quickly as possible. Particularly in large organizations, changes bring with them substantial costs of modernization, integration and maintenance of IT systems.

In organizations with a more complex IT architecture, there is an absolute need for central change management - their planning and implementation (e.g., based on ITIL).

It is necessary to ensure proper interoperability of systems and security resulting from the correct implementation of all changes (Kalaimani, 2016). Each implemented IT project is approved in accordance with the procedures for the responsibility of individual employees, documentation, division into development, testing and production works, authorizations, approval, and so on.

Examples of areas and activities related to Change management and business processes continuous improvement in the lights of the Determinants of IT system for RTE are presented in Table 2.

In many cases of IT systems implementation, there is a need to divide the IT project into IT design project and the implementation project itself. 
Table 2. Exemplary determinants of IT system for RTE

(Source: Kisielnicki and Markowski, 2021)

\begin{tabular}{|c|c|c|}
\hline No. & Determinants of IT System for RTE & $\begin{array}{l}\text { IT System / } \\
\text { Solution }\end{array}$ \\
\hline \multicolumn{3}{|c|}{ Implementation \& Development of IT systems being the prime information sources } \\
\hline 1 & $\begin{array}{l}\text { Improved functionalities or implementation of new functionalities of IT systems } \\
\text { used by enterprise }\end{array}$ & \multirow{2}{*}{$\begin{array}{l}\text { CRM, ERP, MES, } \\
\text { SCADA, SCM, ... }\end{array}$} \\
\hline 2 & Implementation of new IT systems & \\
\hline \multicolumn{3}{|c|}{ Integration of people, information and business processes } \\
\hline 3 & $\begin{array}{l}\text { Securing the customers access to services\&products via numerous communication } \\
\text { channels. }\end{array}$ & \multirow{2}{*}{$\begin{array}{l}\text { Multichannel } \\
\text { service }\end{array}$} \\
\hline 4 & $\begin{array}{l}\text { Combining communication channels with the view of providing employees } \\
\text { with proper info. }\end{array}$ & \\
\hline 5 & Collective single window access to data and information. & \multirow{2}{*}{ Portal } \\
\hline 6 & Portal based automated work and documents flow & \\
\hline 7 & Options for parallel work of people in various locations and time zones & \multirow{2}{*}{ Co-operation } \\
\hline 8 & $\begin{array}{l}\text { Providing information about the status of co-workers' activities and awareness } \\
\text { of their activities. }\end{array}$ & \\
\hline 9 & Data provision to the user in the form and time favored by him/her. & \multirow{2}{*}{$\begin{array}{l}\text { Business } \\
\text { Intelligence }\end{array}$} \\
\hline 10 & Integration of a multitude of data coming from various sources. & \\
\hline 11 & $\begin{array}{l}\text { Securing the organization's ability to obtain, manage and provide customer, product } \\
\text { or service information in real time }\end{array}$ & \multirow{2}{*}{$\begin{array}{l}\text { Knowledge } \\
\text { Management }\end{array}$} \\
\hline 12 & $\begin{array}{l}\text { Support for the organization's continues learning process and application of } \\
\text { knowledge at hand }\end{array}$ & \\
\hline 13 & $\begin{array}{l}\text { Creating a standard model for the enterprise key information objects integration } \\
\text { and management }\end{array}$ & \multirow{2}{*}{$\begin{array}{l}\text { Master Data } \\
\text { Management }\end{array}$} \\
\hline 14 & Securing high quality of data & \\
\hline 15 & $\begin{array}{l}\text { Data translation from one format to another (easy and agile translation between } \\
\text { systems) }\end{array}$ & \multirow{2}{*}{$\begin{array}{l}\text { Integration } \\
\text { Broker }\end{array}$} \\
\hline 16 & Securing easy access of applications to data exchange mechanisms & \\
\hline 17 & $\begin{array}{l}\text { Configuration, execution, monitoring and adjustment of business processes } \\
\text { with IT systems }\end{array}$ & \multirow{2}{*}{$\begin{array}{c}\text { Business Process } \\
\text { Management }\end{array}$} \\
\hline 18 & $\begin{array}{l}\text { Business events management (e.g. Complex Event Processing), performing analyses } \\
\text { and studying relationships between numerous events and triggers }\end{array}$ & \\
\hline \multicolumn{3}{|c|}{ Change management $(\mathrm{ChM})$ and business processes continuous improvement (BPCI) } \\
\hline 19 & Managing the processes of obtaining permits and documentation regarding changes & \multirow{2}{*}{$\begin{array}{l}\text { Ability for ChM } \\
\text { and BPCI }\end{array}$} \\
\hline 20 & Securing ergonomics, proper training and comfort work of systems users & \\
\hline
\end{tabular}


Preparation for implementation (IT design project) of IT solutions for business working in real time requires a coherent vision of the target solution. This can be achieved, for example, using the MUST methodology, which has been developed based on experience from projects in Danish and American organizations (Bødker, et al., 2009).

Thinking and acting from this coherent vision can help the company and its employees deal with postimplementation problems. Issues that often result from IT projects are, for example, the lack of expected improvements, significant budget and schedule overruns, difficulties in implementing tasks using new IT systems or their experience and qualifications (Trocki, 2017).

Such a coherent vision includes suggestions or recommendations for IT systems, work organization and an analysis of the qualifications that users will need to perform their work in a "new", changed organization using new IT systems. The ongoing information efforts of the implementation team and supporters enable employees and other stakeholders to make their own assessments, which can then be integrated into the final design proposal. The aim is therefore to integrate IT systems and work organization.

The result of preparing a project (design project) is one or more coherent visions to achieve the goals, needs and potentials underlying the company's business and IT strategies (Bødker, et al., 2009). The visions describe the future use of IT, including the functions of IT systems, interfaces, ways of interaction and the technical platform. The vision also takes into account the organization of work and the required qualifications of the staff. This provides a basis for deciding which of the prepared visions for the future use of IT best meets the business goals and user needs for IT support in their work.

Based on MUST methodology, the proposed activities of IT design project for RTE have been listed in the Table 3.

Table 3. Proposed activities of IT design project for RTE, based on MUST methodology

(Source: Own research based on: Bødker, et al., 2009)

\begin{tabular}{|c|l|}
\hline No. & \multicolumn{1}{|c|}{ Proposed activities of IT design project for RTE, based on MUST methodology } \\
\hline 1 & $\begin{array}{l}\text { Performance of works on clarification: } \\
\text { 1) The purpose of the project and its connection with the company's strategies } \\
\text { 2) Fields on which the project will focus } \\
\text { 3) Level of detail } \\
\text { 4) Clarity of the company's business strategy and IT strategy }\end{array}$ \\
\hline 2 & $\begin{array}{l}\text { Analysis of the company's environment, including factors such as the overall market situation of the com- } \\
\text { pany; legislation to which the company and its products and services are subject; customers and suppliers; } \\
\text { competitors; as well as known and new technologies (not only in the field of IT). }\end{array}$ \\
\hline 3 & $\begin{array}{l}\text { Analysis of the company's business strategy, related business areas and processes to identify problems, } \\
\text { bottlenecks and other weak relationships. Identifying areas that need to be strengthened } \\
\text { and identifying general IT needs that are measures for this purpose. }\end{array}$ \\
\hline 4 & $\begin{array}{l}\text { Analysis of existing IT strategies for business or setting priorities in IT systems planned in the company. } \\
\text { Assessment whether the company's IT strategy extends to the design project objectives. } \\
\text { Review the IT strategy to locate the job domains to be supported by IT systems and how the IT strategy } \\
\text { supports the business strategy. }\end{array}$ \\
\hline
\end{tabular}


Table 3. Proposed activities of IT design project for RTE, based on MUST methodology (cont.) (Source: Own research based on: Bødker, et al., 2009)

\begin{tabular}{|c|c|}
\hline No. & Proposed activities of IT design project for RTE, based on MUST methodology \\
\hline 5 & $\begin{array}{l}\text { An analysis of how a new technological potential can radically influence and change a business strategy, } \\
\text { possibly creating entirely new business ventures. }\end{array}$ \\
\hline 6 & $\begin{array}{l}\text { Research, study of selected fields of work and understanding of the rationale determining current practices. } \\
\text { Prioritizing the goals, problems and needs for which the project team will develop design visions } \\
\text { in the innovation phase. }\end{array}$ \\
\hline 7 & $\begin{array}{l}\text { Gaining specific experience in a selected field of work, for example, through interviews and document } \\
\text { analysis. }\end{array}$ \\
\hline 8 & $\begin{array}{l}\text { Preparation: } \\
\text { 1. Prioritized list of goals, problems and needs } \\
\text { 2. Ideas for: IT support, changes in work organization and new user qualifications }\end{array}$ \\
\hline 9 & $\begin{array}{l}\text { Determining whether there are standard systems for the disclosed needs of the company to meet them. } \\
\text { Gathering and systematizing experiences concerning the use and application of these systems. }\end{array}$ \\
\hline 10 & $\begin{array}{l}\text { Collect and further develop ideas for new IT systems and work organization previously discovered during } \\
\text { the process or during job interviews, with a particular focus on management and employee requirements } \\
\text { for the future use of technology. }\end{array}$ \\
\hline 11 & $\begin{array}{l}\text { Complementing the design vision by making one or more prototypes illustrating the functionality } \\
\text { of the proposed IT systems }\end{array}$ \\
\hline 12 & $\begin{array}{l}\text { Ensuring that future users acquire the qualifications and skills necessary to use the new technology } \\
\text { in the proposed work organization. }\end{array}$ \\
\hline 13 & $\begin{array}{l}\text { Determining the predictable positive and negative consequences of implementing project visions: conse- } \\
\text { quences for the entire company, for individual groups of employees, for relations between departments, } \\
\text { as well as for relationships with customers and suppliers. }\end{array}$ \\
\hline 14 & Strategic plan for technical and organizational implementation of project visions. \\
\hline 15 & Presentation of a vision of the overall change and a proposal of priorities. \\
\hline
\end{tabular}

RTE seems to be an increasingly interesting prospect for enterprises from various industries. Hence, the emerging IT requirements from business decision makers. Our research shows that the creation of an IT system enabling RTE operation should be based on the above determinants regarding the integration of people, information and business processes, expansion of the existing management support systems or implementation of new ones, change management and business processes continuous improvement (BPCI) and the appropriate methodology to design or for preparation of the implementation.

\section{Conclusion}

Due to the complexity of operations of modern enterprises, their various business processes, activities in many countries of the world, changing internal and external conditions, it can be stated that they need various IT systems for effective management, that is, ERP, CRM, BI, SCM, SCADA, HCM and so on.

The requirements set by IT by the RTE concept (realtime information processing enterprise) necessitate the use of integration technologies that enable immediate data exchange between both the company's IT 
systems and its business partners. Such integration can be carried out with the use of various technologies understood as middleware (cloud or on-premise).

Hence, in the case of RTE, one can speak of a platform of cooperating IT systems supporting management.

In this work, analyzing RTE as a platform of support management systems:

1) Examples of business areas with real-time business processes are indicated;

2) The basic RTE requirements for IT were presented regarding: real time monitoring, real-time access to information and acceleration of business processes;

3) The proposed determinants of IT system design for IT were presented, including:

a) Implementation \& development of IT systems,

b) Integration of people, information and business processes,

c) Change management and continues improvement of the enterprise processes,

d) IT design;

4) The MUST methodology was proposed as the basis for the preparation of IT technology implementation for RTE;

5) The management cockpit has been proposed as the central reporting element for real-time monitoring.

Further research is planned to:

- deepening the analysis of information on the impact of determinants of IT system design for RTE in international companies,

- analysis of the use of IoT (Internet of Things) in obtaining data and managing the supply chain and production under RTE,

- studies on common areas of RTE and Smart Factory (in the Industry 4.0 concept),

- checking how the Social, Mobile, Analytics, cloud technologies can support RTE,

- to identify the effects and risks of DARQ techno distributed ledger (DLT), artificial intelligence (AI), augmented reality (XR) and quantum computing technologies on RTE enterprises (Q). DARQ is an important stage in the evolution of ICT development, it supplements the current technology known as SMAC (Social, Mobile, Analytics, Cloud)

\section{$5 \quad$ References}

[1] Bødker, K., Kensing, F. and Simonsen, J., 2009. Participatory IT Design. Designing for business and workplace realities. The MIT Press Cambridge, Massachusetts, London, England, pp.5657.

[2] Brynjolfsson, E., McAffee, A., 2017. How AI Fits Into Your Science Team. What it can - and cannot - do for your organization. Harvard Business Review, hbr.org., 21 July 2017, access: 16 April 2019.

[3] Cundius, C., Alt, R., 2017. A Process-Oriented Model to Business Value - the Case of Real-Time IT Infrastructures. Proceedings: 50th Hawaii International Conference on System Sciences, 4-7 January 2017, pp.5017-5026.

[4] Dachs, B., Kinkel, S., Jäger, A., 2019. Bringing it all back home? Backshoring of manufacturing activities and the adoption of Industry 4.0 technologies. Journal of World Business, 54(6), 101017, 6 .

[5] Davcheva, E., Benlian, A., 2018. Visual Decision-Making in Real-Time Business Intelligence: A Social Media Marketing Example. Proceedings: the 51st Hawaii International Conference on System Sciences, 2-6 January 2018, pp.13191328.

[6] Davenport, T.H., Ronanki, R., 2018. Artificial Intelligence for the Real World. Don't start with moon shots. Harvard Business Review, January/February 2018.

[7] Dirican, C., 2015.The Impacts of Robotics, Artificial Intelligence On Business and Economics. Conference materials: World Conference on Technology, Innovation and Entrepreneurship, Procedia - Social and Behavioral Sciences 195, pp.564-573.

[8] Garro, J.M., Bazán, P., Díaz, J., 2016. Using BAM and CEP for Process Monitoring in Cloud BPM. Journal of Computer Science and Technology, 16(1), p.39.

[9] George, G., Osinga, E.C., Lavie, D., Scott, B.A., 2016. Big Data and Data Science Methods for 
Management Research. Academy of Management Journal, 59(5), pp.1493-1507.

[10] Herrmann, F., 2018. The Smart Factory and Its Risks. Systems, 6(38).

[11] Hofman, W.J., Bastiaansen, H.J.M., 2014. Roadmap Towards a Smart Logistics Ecosystem, Conference material: 7th European Conference on ICT for Transport Logistics-ECITL 2014, pp.5-7 November 2014, Dortmund, Germany, 2014, 5.

[12] Hongren, C.T., Datar, S.M., Rajan, M.V., 2015. Cost accounting: A managerial emphasis. Prentice Hall, wyd.15, Upper Saddle River, New Jersey, USA.

[13] Hwang, H., Lee, S., Kim, S., Lee, S., 2018. Building an Analytical Platform of Big Data for Quality Inspection in the Dairy Industry: A Machine Learning Approach. Journal of Intelligent Information Systems, 24(1), pp.125-140.

[14] Hwang, M., 2018. Graph Processing Using SAP HANA: A Teaching Case. e-Journal of Business Education \& Scholarship of Teaching, 12(2), pp.155-165.

[15] Kalaimani, J., 2016. Managing Projects Using SAP Solution Manager. In: SAP Project Management Pitfalls. Apress, Berkeley, CA, USA.

[16] Karnouskos, S., 2015. Effective Change Management in Modern Enterprises. Linneaus University, Faculty of Informatics, 16.

[17] Kaymaz, F., 2015. Managing Complexity and Speed of Processes in the Organizations - A Philosophical and Practical Approach. Philosophy Study, 5(7), pp.361-371.

[18] Kejariwal, A., and Orsini, F., 2016. On the Definition of Real-Time: Applications and Systems. Conference material: 2016 IEEE Trustcom/BigDataSE/ISPA, 23-26 August 2016, Tianjin, China.

[19] Kekwaletswe, R.M., Lesole, T., 2016. A Framework for Improving Business Intelligence through Master Data Management. Journal of South African Business Research.

[20] Kisielnicki, J., 2017. Zarzadzanie i informatyka (Management and IT). Warsaw: Placet, 24.

[21] Kisielnicki, J., Markowski, M.M., 2021. Organizations Operating in Real Time (Real-Time Enterprise) and the Role of IT as a Tool Supporting Their Management Systems. In Khosrow-Pour
D.B.A., M. (Ed.), Encyclopedia of Organizational Knowledge, Administration, and Technology, IGI Global, pp.582-596, http://doi:10. 4018/978-1-7998-3473-1.ch043

[22] Kolbjørnsrud, V., Amico, R., Thomas, R.J., 2016. How Artificial Intelligence Will Redefine Management, Harvard Business Review, hbr.org, 2 November 2016, access: 16 April 2019.

[23] Korotina, A., Mueller, O., Debortoli, S., 2015. Real-time Business Process Intelligence. Comparison of different architectural approaches using the example of the order-to-cash process. Procedings.: the 12th International Conference on Wirtschaftsinformatik, 4-6 March 2015, Osnabrueck, Paper 114.

[24] Lai, Ch.T.A., Jackson, P.R, Jiang, W., 2018. Designing Service Business Models for the Internet of Things: Aspects from Manufacturing Firms. American Journal of Management Science and Engineering, 3(2), pp.7-22.

[25] Leonardi, P., 2020. The Nuts and Bolts of Digital Transformation: You're Going Digital - Now What?, MIT Sloan Management Review, 61(2), pp.1-7.

[26] Macià, H., Valero, V., Díaz, G., Boubeta-Puig, J., Ortiz, G., 2016. Complex Event Processing Modeling by Prioritized Colored Petri Nets. IEEE Access, 4, pp.7425-7438.

[27] Makridakis S., 2017. The Forthcoming Artificial Intelligence (AI) Revolution: Its Impact on Society and Firms. Futures, 90, pp.46-60.

[28] Markowski, M., 2012. Przedsiębiorstwo Czasu Rzeczywistego jako Element Gospodarki Elektronicznej (Real Time Enterprise as an Element of Digital Economy). Zeszyty Naukowe Uniwersytetu Szczecińskiego, Nr 702 Ekonomiczne Problemy Usług Nr 87, pp.279-288.

[29] Martínez-Fernández, S., Jovanovic, P., Franch, X., Jedlitschka, A., 2018. Towards Automated Data Integration in Software Analytics. Procedings.: BIRTE'18, the Twelfth International Workshop on Real-Time Business Intelligence and Analytics, 27 August, 2018, Rio de Janeiro, Brazylia.

[30] Mathes, C.A., 2016. Big Data Has Unique Needs for Information Governance and Data Quality. Journal of Management Science and Business Intelligence, 1(1), 16. 
[31] McDonald, K., Wilmsmeier, A., Dixon, D.C., Inmon, W.H., 2015. Mastering the SAP Business Information Warehouse. John Wiley \& Sons.

[32] Nel, C.B.H., Jooste, J.L., 2018. A Policy Framework for Integrating Smart Asset Management within Operating Theatres in a Private Healthcare Group to Mitigate Critical System Failure. Proceedings: 31st Conference on Condition Monitoring and Diagnostic Engineering Management, COMADEM 2018, North-West University, RSA, 156.

[33] Ouarhim, A., Baïna, K., 2019. Towards a realtime business processes validation algorithm. Procedia Computer Science, 148, pp.580-589.

[34] Pan, Y.H., 2016. Heading toward artificial intelligence 2.0. Engineering, 2(4), pp.409-413.

[35] Park, Y., El Sawy, O.A., Fiss, P.C., 2017. The Role of Business Intelligence and Communication Technologies in Organizational Agility: A Configurational Approach. Journal of the Association for Information Systems, 18(9), pp.648-686.

[36] Park, Y.K., El Sawy, O.A. Hong., T., 2020. Digital Transformation to Real-Time Enterprise to Sustain Competitive Advantage in the Digitized World: The Role of Business Intelligence and Communication Systems. Korea Business Review. 신년 특별호, 24, pp.105-130.

[37] Patri, O.P., Panangadan, A.V., Sorathia, V.S., Prasanna, V.K., 2016. Sensors to events: semantic modeling and recognition of events from data streams. International Journal of Semantic Computing, 10(4), pp.461-501.

[38] Rudowski, M.H., 2015. Information Systems in Management of Polish Railway Companies of PKP Group in Aspects Of Technology And Economy. Information Systems in Management, 4(3), pp.193-204.

[39] Šibalija, T., 2018. Business Process Management And Automation: Key Issues. International Journal "'Advanced Quality", 46(3-4).

[40] Sikri, M., 2015. Survey of the Adaptive QoSaware discovery approaches for SOA. International Journal of Computer Science and Information Security (IJCSIS), 13(12).

[41] Snabe, J.H., Rosenberg, A., Møller, C., Scavillo, M. (2009). Business Process Management - The SAP Roadmap. Galileo Press.
[42] Song, R., Wang, Y., Huang, L., 2017. An Ontology-based Approach for Context Modeling in Collaborative Services. Conference materials: The Fourth International Symposium on Management, Innovation \& Development (MID2017), Beijing, China.

[43] Tank, D.M., 2015. Enable Better and Timelier Decision-Making Using Real-Time Business Intelligence System. International Journal of Information Engineering and Electronic Business (IJIEEB), January 2015, 7(1), pp.43-48.

[44] Trocki, M. (red), 2017. Metodyki i standardy zarzadzania projektami (Methodologies and Standards of Project Management). Warszawa: PWN.

[45] Vasarhelyi, M.A., Teeter, R.A., Krahel, J.P., 2010. Audit Education and the Real-Time Economy. Issues in Accounting Education, 25(3), pp.405-423.

[46] Wua, D., Olsonb, D.L., Dolgui, A., 2017. Artificial Intelligence in Engineering Risk Analytics. Engineering Applications of Artificial Intelligence, 65, pp.433-435.

[47] Youssef, J.R., Zacharewicz, G., Chen, D., Vernadat, F., 2018. EOS: Enterprise Operating Systems. International Journal of Production Research, 56(8), pp.2714-2732.

[48] Yuan, X., 2016. Study on the Practical Management of Human Resources Cost under the Auxiliary of Financial Accounting. Proceedings: the 4th International Education, Economics, Social Science, Arts, Sports and Management Engineering Conference (IEESASM 2016), 13-14 August 2016, Yinchuan, Ningxia, China, 999.

[49] Zhang, X., Chen, Y., 2017. An Artificial Intelligence Application In Portfolio Management. Proceedings: International Conference on Transformations and Innovations in Management (ICTIM-17), 9-10 September 2017, Shanghai, China, 37.

[50] Zhang, Z., Liu, Ch., Zhang, S, Li, X., Han, Y., 2018. A Service-Based Method for Multiple Sensor Streams Aggregation in Fog Computing. Wireless Communications and Mobile Computing, 2018(11), pp.1-11. 